\title{
APLIKASI METODE ARIMA BOX-JENKINS UNTUK MERAMALKAN KASUS DBD DI PROVINSI JAWA TIMUR
}

\author{
Muhammad Bintang Pamungkas ${ }^{1}$, Arief Wibowo ${ }^{2}$ \\ ${ }^{1,2}$ Departemen Biostatistika dan Kependudukan \\ Fakultas Kesehatan Masyarakat, Universitas Airlangga \\ Alamat Korespondensi: Muhammad Bintang Pamungkas \\ Email: muhbintangpamungkas@gmail.com
}

\begin{abstract}
The Box-Jenkins forecasting method is one of the time series forecasting methods. This method uses past values as dependent variables and independent variables are ignored. Box-Jenkins (ARIMA) method has advantages that can be used on non-stationary data, can be used on all data patterns including seasonal data patterns so this method can be used to predict cases of DHF in East Java Province. This research was conducted to determine the best model with seasonal ARIMA forecasting model and also to analyze the result of DHF case forecasting in East Java Province. The analysis result shows that the best model for DHF case in East Java Province is ARIMA $(1,1,2)(2,1,1)^{12}$. The best model has fulfilled the test requirement that is parameter significance test and diagnostics check. Forecasting results show the number of DHF cases in 2017-2018 will experience an upward trend. The total number of DHF cases in 2017 was 14,277 cases and increased to 22,284.54 DHF cases in 2018. The forecasting results showed that the highest peak of DHF cases occurred in January 2017 with 1,914.22 cases and then decrease in the next month until the lowest case occurred in October with 768.46. The forecast for 2018 also shows that the highest DHF cases occurred in January with 3455.55 and declined to the lowest in October with 1126.49 cases. MAPE value in the forecast is $43.51 \%$. The MAPE value indicates that the forecasting is good enough, adequate and feasible to use.
\end{abstract}

Keywords: ARIMA, time series, seasonal, DHF case

\begin{abstract}
ABSTRAK
Metode Box-Jenkins adalah salah satu metode peramalan time series. Metode ini menggunakan nilai di masa lalu sebagai variabel dependen dan variabel independen diabaikan. Metode Box-Jenkins memiliki kelebihan yaitu dapat digunakan pada data yang tidak stasioner dapat digunakan pada semua pola data termasuk pola data musiman sehingga metode ini dapat digunakan untuk meramalkan kasus DBD di Provinsi Jawa Timur. Penelitian ini dilakukan untuk menentukan model terbaik dengan model peramalan ARIMA musiman dan juga menganalisis hasil peramalan kasus DBD di Provinsi Jawa Timur. Hasil analisis menunjukkan model terbaik untuk kasus DBD di Provinsi Jawa Timur adalah ARIMA $(1,1,2)(2,1,1)^{12}$. Model terbaik sudah memenuhi syarat uji yaitu uji signifikansi parameter dan pemeriksaan diagnostik. Hasil peramalan menunjukkan jumlah kasus DBD mengalami tren kenaikan. Jumlah total kasus DBD tahun 2017 adalah 14.277 kasus dan meningkat menjadi 22.284,54 kasus DBD pada tahun 2018. Hasil peramalan menunjukkan jika puncak kasus DBD tertinggi terjadi pada bulan Januari 2017 dengan 1.914,22 kasus kemudian terjadi penurunan kasus pada bulan selanjutnya hingga kasus terendah terjadi pada bulan Oktober dengan 768,46. Hasil peramalan tahun 2018 juga menunjukkan jika kasus tertinggi terjadi pada bulan Januari dengan 3455,55 dan menurun sampai pada kasus terendah terjadi di bulan Oktober dengan 1126,49 kasus. Nilai MAPE pada peramalan adalah 43,51\%. Nilai MAPE tersebut menunjukkan bahwa peramalan cukup baik, memadai dan layak untuk digunakan.
\end{abstract}

Kata kunci: ARIMA, deret waktu, musiman, kasus DBD

\section{PENDAHULUAN}

Peramalan adalah suatu kegiatan yang memiliki tujuan untuk menduga atau memperkirakan suatu peristiwa di masa yang akan datang serta merupakan alat bantu dalam melakukan perencanaan yang efektif dan efisien (Makridakis et al., 1999). Pendugaan jumlah data di masa depan dengan memanfaatkan data di masa lalu berdasarkan suatu persamaan yang matematis. Pemilihan metode peramalan 
tegantung dari pola datanya, faktor yang mempengaruhi hasil peramalan dan faktor lainnya. Metode peramalan dibagi menjadi 2 jenis yaitu obyektif dan subyektif. Metode peramalan obyektif dibagi menjadi deret berkala dan model regresi dan model subyektif terdiri dari analogies, delphi, PERT dan survey techniques (Makridakis et al., 1999).

Metode peramalan dengan analisis berdasarkan data waktu adalah metode peramalan time series atau deret berkala. Model ini melakukan pengamatan secara berkesinambungan terhadap variabel yang terdiri dai waktu yang sama seperti tiap hari, minggu, bulan dan tahun. Metode peramalan deret waktu digunakan untuk mengetahui perkembangan suatu kejadian dan dapat digunakan membuat ramalan berdasarkan garis regresi atau tren. Pada dasarnya, peramalan deret waktu merupakan nilai di masa depan yang berupa fungsi matemasis dari nilai di masa lampau dan model fungsinya berdasar fungsi deret waktu itu sendiri tanpa ada pengaruh dari variabel luar (Baroroh, 2013).

Metode deret berkala dibedakan menjadi beberapa teknik antara lain yaitu pemulusan (smoothing), dekomposisi dan Box-Jenkins atau ARIMA. Metode BoxJenkins memakai variabel dependen yaitu data di masa lampau sedangkan variabel independen diabaikan. Metode ini memiliki beberapa keuntungan seperti tidak membutuhkan pola data yang stasioner dan dapat digunakan pada data yang mengandung pola musiman. Metode Box-Jenkins tediri dari AR (Autoregressive), MA (Moving Average), ARMA (untuk data stasioner), ARIMA (untuk data yang tidak stasioner) dan ARIMA musiman atau SARIMA (untuk data yang tidak stasioner dan musiman).

Kegiatan peramalan dapat digunakan dalam berbagai masalah yang ada di masyarakat termasuk dalam masalah kesehatan. Salah satu masalah umum yang muncul setiap tahun di negara tropis seperti Indonesia adalah masalah Deman
Berdarah Dengue (DBD). Kecenderungan sifat penyakit DBD yang mudah menyebar, lingkup persebaran nyamuk yang luas dan didukung oleh mobilitas penduduk dan kepadatan penduduk di Indonesia yang semakin tinggi menyebabkan DBD sulit untuk diberantas. Data jumlah kasus DBD dapat digolongkan sebagai data deret waktu maka data kasus DBD dapat digunakan untuk peramalan menggunakan metode peramalan Box-Jenkins.

DBD merupakan salah satu masalah kesehatan utama di Indonesia. DBD ditularkan ke manusia melalui nyamuk aedes aegypt yang terinfeksi virus dengue (Tantawichien, 2012). Penyakit DBD ditemukan pertama kali di Kota Surabaya tahun 1968 dengan jumlah kasus sebanyak 58 dan 24 diantaranya meninggal, sejak itu DBD menyebar ke seluruh Indonesia (Kemenkes RI, 2010). DBD disebabkan oleh virus dengue dari genus flavivirus, famili flaviviridae (Srikiatkhachorn et al., 2010)

Indonesia adalah negara dengan jumlah kasus DBD tertinggi di Asia Tenggara (Halide et al., 2011). Iklim tropis di Indonesia sangat memungkinkan untuk perkembangbiakan nyamuk vektor DBD dan nyamuk dapat menyebar luas di berbagai wilayah di Indonesia kecuali pada ketinggian lebih dari 1000 meter.

Provinsi Jawa Timur merupakan salah satu provinsi di Indonesia dengan kasus DBD tertinggi diantara 35 provinsi lainnya. Menurut Direktorat Jendral Pencegahan dan Pengendalian Penyakit, Kemenkes RI pada tahun 2016, menunjukkan bahwa jumlah kasus DBD di Provinsi Jawa Timur berada di peringkat 2 dari 35 provinsi. Kasus DBD di Provinsi Jawa Timur sebanyak 24.461 kasus DBD selama periode tahun 2016. Jumlah kasus DBD di Provinsi Jawa Timur tersebut meningkat dibandingkan dengan tahun sebelumnya dengan 20.129 di tahun 2015.

Angka Kesakitan (Incidence Rate) DBD di Provinsi Jawa Timur sebesar 64,8 per 100.000 penduduk. Angka tersebut menunjukkan bahwa Provinsi Jawa Timur 
masih belum mencapai target yang dicanangkan yaitu sebesar 49 per 100.000 penduduk. Angka tersebut juga mengalami kenaikan dibandingkan dengan tahun sebelummnya yaitu sebesar 54,18 per 100.000 penduduk. Angka Kematian (Case Fatality Rate) DBD di Provinsi Jawa Timur menunjukkan nilai sebesar $1,4 \%$. Angka tersebut juga masih belum mencapai target yang dicanangkan yaitu kurang dari sama dengan $1 \%$. Angka Kematian yang melebihi target di Provinsi Jawa Timur pada Tahun 2016 meningkat dari tahun 2015. Terdapat peningkatan jumlah kabupaten dan kota yang melebihi target $C F R$ yaitu sebanyak 24 kabupaten dan kota dibandingkan dengan tahun 2015 sebanyak 18 kabupaten dan kota. (Dinkes Provinsi Jawa Timur, 2016).

Penyakit DBD merupakan penyakit yang mempunyai perjalanan yang pesat dari awal terkena sampai terdiagnosa DBD, sehingga sering terjadi fatal dan penanganan terlambat yang menyebabkan kematian (Sukowati, 2010). Melihat perkembangan penyakit DBD di Provinsi Jawa Timur maka diperlukan suatu metode peramalan jumlah kasus DBD di Provinsi Jawa Timur di masa depan yang nantinya dapat digunakan sebagai tindakan preventif untuk mencegah peningkatan kasus DBD di Provinsi Jawa Timur.

\section{METODE PENELITIAN}

Penelitian ini termasuk jenis penelitian non reaktif atau unobstruktive. Penelitan non reaktif adalah penelitian yang tidak memerlukan respons dari subyek yang diteliti dan tidak ada interaksi antara peneliti dan subyek penelitian. Data yang digunakan pada penelitian adalah data sekunder. Data yang digunakan adalah data bulanan kasus DBD yang tercatat dan dilaporkan di Dinas Kesehatan Provinsi Jawa Timur mulai dari Januari 2008 sampai Februari 2016 atau sebanyak 108 titik data historis.

Data kasus DBD yang didapat dari Dinas Kesehatan Provinsi Jawa Timur kemudian diolah dan dianalisis secara komputerisasi. Tujuan dari analisis pada data yaitu agar menghasilkan penjelasan terkait hasil dan menjadi lebih mudah dipahami serta dapat ditarik kesimpulan yang kemudian dapat dirumuskan saran dan rekomendasi.

Langkah dalam analisis data pada metode Box-Jenkins terdiri dari beberapa tahap. Tahap pertama adalah pemeriksaan pola data. Plotting data diperlukan untuk melihat tren dan pola dalam data. Langkah selanjutnya yaitu dilakukan uji stasioneritas data. Uji stasioneritas dalam varians dilakukan dengan menggunakan Transformasi Box-Cox. Jika nilai rounded value atau lambda ( $\lambda$ ) lebih dari sama dengan 1, maka data dikatakan telah stasioner dalam varians. Namun jika tidak maka harus dilakukan transformasi sampai nilai rounded value pada Box-Cox bernilai 1 atau lebih dari 1. Uji stasioneritas dalam means dilakukan dengan menganalisis grafik ACF dari data yang sudah stasioner dalam varians. Data yang telah stasioner dalam means maka proses dapat dilanjutkan ke langkah selanjutnya, yaitu identifikasi model sementara. Namun, apabila data belum stasioner pada nilai rata-ratanya (means), maka dilakukan proses difference. Tingkatan difference juga akan menentukan nilai (d) pada model, jika terdapat pola musiman maka juga dilakukan proses difference musiman sebanyak pola musiman yang berulang. Pola yang terjadi setiap 12 bulan sekali maka proses difference dilakukan 12 kali atau dapat diartikan sebagai difference musiman tingkat 1. Nilai difference musiman juga akan menentukan nilai (D) pada model.

Data yang sudah stasioner baik dalam varians maupun means maka langkah selanjutnya adalah menetapkan model sementara (tentative) ARIMA $(p, d, q)(P, D, Q)^{\mathrm{s}}$ yang sesuai. Data yang tidak mengalami pembedahan (difference) maka nilai $(d)$ adalah 0 , jika data stasioner setelah difference ke-1 maka $\mathrm{d}=1$ dan seterusnya. Begitu juga pada data 
musiman, jika data mengalami difference ke 1 maka nilai $(D)$ adalah 1 dan seterusnya. Menetapkan ordo $p, q, P$, dan $Q$ dapat dilihat dengan mengamati pola Autocorrelation Function (ACF) dan Partial Autocorrelation Function (PACF) yang sudah dilakukan difference musiman.

Tahap selanjutnya adalah estimasi parameter model, apakah paramameter yang didapat dari model SARIMA sementara signifikan atau tidak. Model signifikan jika nilai signifikansi kurang dari alpha $(\alpha)$ dengan nilai $\alpha$ adalah 0,05 . Tahap selanjutnya adalah pemeriksaan diagnostik untuk membuktikan model cukup memadai atau sudah baik untuk digunakan dalam peramalan. Pemeriksaan diagnostik yang dilakukan yaitu uji white noise dan uji normalitas.

Uji white noise pada residual menggunakan uji Ljung-Box dengan hipotesis yang diuji adalah residual sudah white noise. Residual sudah white noise jika nilai $p$-value lebih dari alpha $(\alpha)$ dengan nilai $(\alpha)$ adalah 0,05 .

Uji normalitas digunakan uji statistik Kolmogorov-Smirnov. Hipotesis yang diuji adalah residual atau error berdistribusi normal. Residual dikatakan berdistribusi normal jika $p$-value lebih dari $(\alpha)$ dengan $(\alpha)$ adalah 0,05 . Model dikatakan baik dan layak jika dapat memenuhi ketiga uji tersebut.

Model ARIMA terbaik yang sudah didapatkan akan digunakan untuk proses peramalan selama 2 tahun mendatang untuk meramalkan kasus DBD. Model terbaik adalah model yang memiliki nilai error yang paling kecil. Data peramalan akan dilakukan evaluasi untuk mengetahui ketepatan hasil peramalan dengan melihat persentasi MAPE dan nilai MAD.

\section{HASIL PENELITIAN}

\section{Gambaran Kasus DBD di Provinsi Jawa Timur}

Pada Gambar 1 menunjukkan sebaran data kasus DBD dari bulan Januari 2008 sampai dengan Desember 2016.

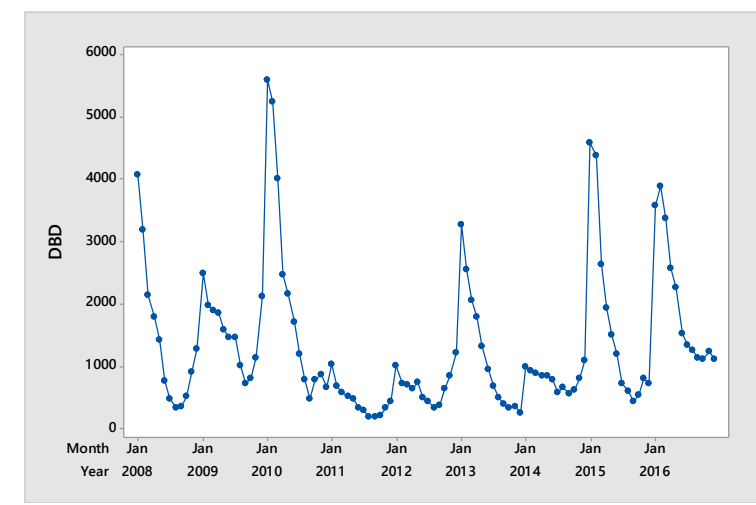

Gambar 1. Plot Data Jumlah Kasus DBD Di Provinsi Jawa Timur

Pada Gambar 1 menunjukkan jika data kasus DBD di Provinsi Jawa Timur cenderung mengalami naik turun atau terjadi fluktuasi data selama tahun 2008 sampai tahun 2016. Kasus tertinggi terjadi pada tahun 2010 dengan jumlah kasus DBD sebesar 26.015 kasus. Kasus DBD menurun secara drastis pada tahun setelahnya yaitu tahun 2011 dengan total kasus selama setahun adalah 5.374 kasus. Terdapat tren selama 3 tahunan pada data kasus DBD di Provinsi Jawa Timur yang berarti bahwa akan terjadi kenaikan kasus DBD selama 3 tahun yang kemudian di tahun setelahnya menurun dan kemudian akan naik untuk 3 tahun selanjutnya.

Pada Gambar 1 juga dapat diidentifikasi terdapat pola musiman. Pola musiman ini dapat dilihat dari puncak pada grafik kasus DBD terjadi setiap bulan Januari pada tiap tahunnya selama 9 tahun terakhir. Peningkatan secara drastis setiap memasuki bulan Januari disebabkan oleh musim penghujan yang terjadi di Provinsi Jawa Timur. Hasil penelitian sebelumnya menunjukkan jika penyakit DBD merupakan penyakit yang terjadi setiap tahun dan merupakan siklus musiman yang dapat diduga sebelumnya (Wahyono et al., 2010). Maka peramalan ini menggunakan metode peramalan Box-Jenkins musiman atau ARIMA musiman untuk menghasilkan hasil yang lebih baik karena mengikuti data yang mengandung pola 
musiman pada data kasus DBD di Provinsi Jawa Timur.

\section{Pemeriksaan Stasioneritas Data Kasus DBD di Provinsi Jawa Timur}

Plot data kasus DBD pada gambar 1 menunjukkan secara visual data masih belum stasioner dalam ragam (varians) dan stasioner dalam rata-rata (menas). Data yang stasioner adalah data yang tidak mengalami kenaikan dan penurunan (Makridakis, 1999). Data yang stasioner fluktuasi datanya berada di sekitar nilai rata-rata dan konstans terhadap waktu.

Data dapat digunakan untuk peramalan jika sudah stasioner, maka data perlu di stasionerkan agar memenuhi syarat asumsi awal. Data dapat tidak stasioner dalam ragam (varians) maupun tidak stasioner dalam rata-rata (means). Data tidak stasioner dalam varians atau ragam maka data akan di transformasikan dengan bantuan transformasi Box-Cox, sedangkan jika data tidak stasioner dalam rata-rata atau means maka data akan dilakukan difference.

Pada Gambar 2 menunjukkan jika data masih belum stasioner dalam varians. Plot pada Box-Cox plot menunjukkan jika nilai rounded value adalah 0,00 untuk selang kepercayaan 95\% dengan batas bawah interval (lower $C L$ ) sebesar $(-0,32)$ dan nilai batas atas interval (upper $C L$ ) sebesar $(0,14)$.

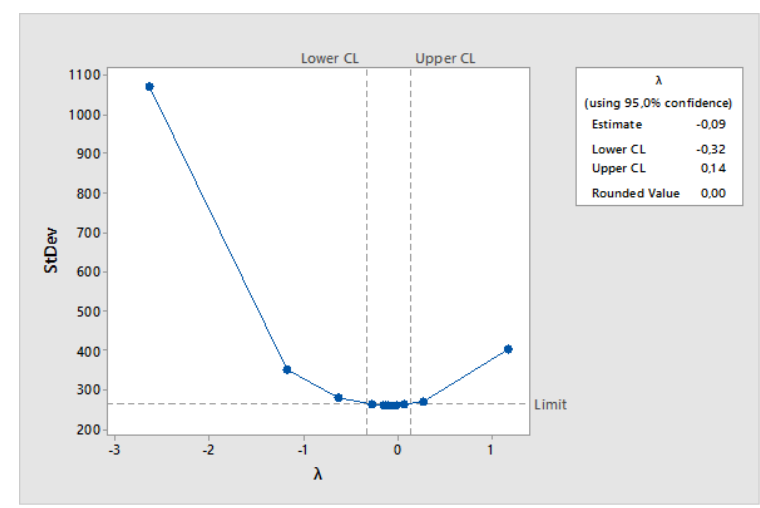

Gambar 2. Box-Cox Plot Kasus DBD

$\begin{array}{ccr}\text { Nilai } & \text { rounded value } & 0,00 \\ \text { menunjukkan jika data masih belum }\end{array}$

stasioner terhadap varians. Data stasioner dalam varians jika nilai rounded value bernilai 1 atau lebih dari 1 (Aritonang, 2009). Data yang belum stasioner dalam varians maka data perlu di transformasikan agar nilai lambda $(\lambda)$ atau rounded value lebih besar sama dengan 1 .

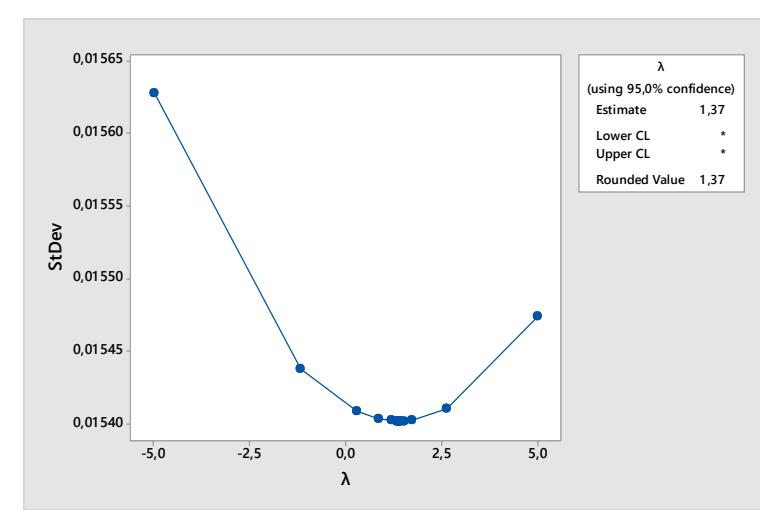

Gambar 3. Box-Cox Plot Kasus DBD Hasil Transformasi

Pada Gambar 3 menunjukkan jika nilai rounded value pada Box-Cox plot sebesar 1,37. Nilai lambda tersebut sudah bernilai lebih besar sama dengan 1 dengan selang kepercayaan sebesar 95\%. Nilai rounded value sebesar 1,37 menunjukkan jika data kasus DBD sudah stasioner dalam varians.

$$
\text { Langkah selanjutnya yaitu }
$$
menentukan data sudah stasioner dalam means atau tidak. Data stasioner dalam means atau tidak dapat dilihat dari plot ACF (Autocorrelation Function). Lag pada plot ACF menunjukkan nilai autokorelasi pada data.

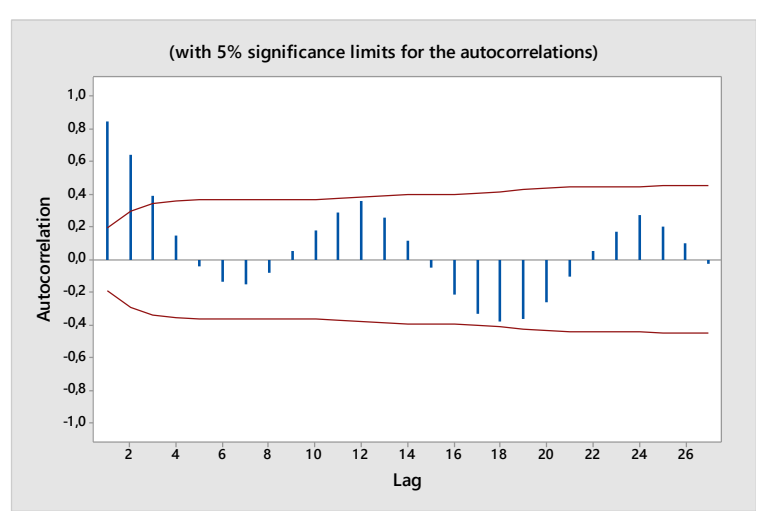

Gambar 4. Plot ACF Data Kasus DBD Transformasi 
Pada Gambar 4 dapat dilihat bahwa 3 lag pertama pada plot ACF menunjukkan melewati garis merah. Garis merah adalah selang kepercayaan atau batas signifikan autokorelasi. Tiga lag pertama pada plot ACF yang telah melewati garis merah menunjukkan data masih terdapat autokorelasi dan data tidak stasioner dalam means. Agar data menjadi stasioner dalam means maka diperlukan proses difference pada data. Proses difference dilakukan dengan cara mengurangi nilai data pada suatu periode dengan nilai data pada periode sebelumnya untuk menghitung nilai selisihnya. Jika dilakukan proses difference 1 kali maka nilai $\mathrm{d}$ adalah 1 pada model.

Gambar 5 menunjukkan plot ACF data kasus DBD setelah dilakukan proses difference 1 kali. Plot ACF menunjukkan jika data masih belum stasioner dalam means dilihat dari banyak lag yang melewati selang kepercayaan. Plot ACF menunjukkan terdapat lag 12 dan lag 24 yang melewati selang kepercayaan. Lag tersebut memperlihatkan jika terdapat pola musiman pada data dan berulang setiap 12 bulan sekali.

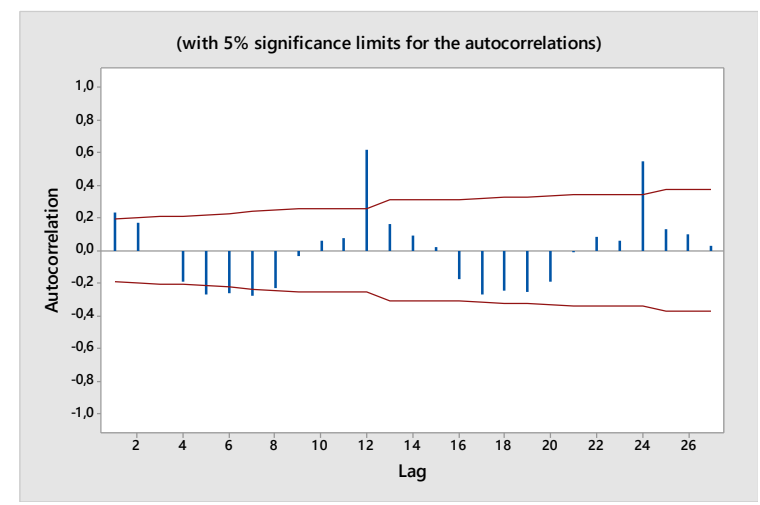

Gambar 5. Plot ACF Kasus DBD Difference 1

Data yang memiliki pola musiman menunjukkan data belum stasioner dalam means maka diperlukan proses difference sekali lagi yaitu difference musiman. Difference musiman 1 kali atau nilai $\mathrm{D}$ adalah 1 pada model. Nilai difference bernilai 12 sesuai dengan pola musiman yang terjadi.

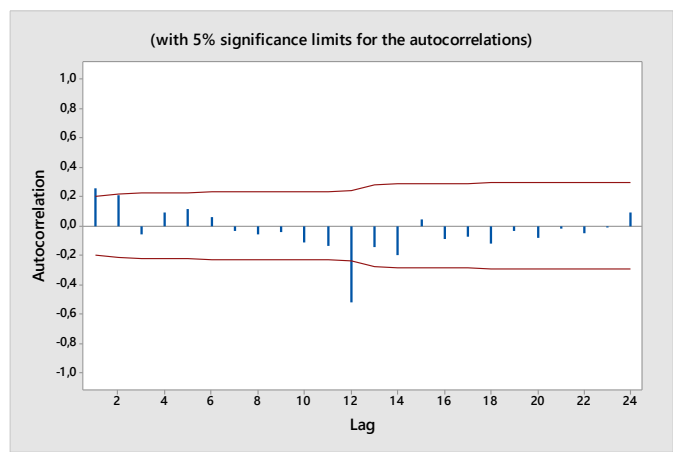

Gambar 6. Plot ACF Data Kasus DBD Difference Musiman 1

Gambar 6 memperlihatkan plot ACF data kasus DBD setelah dilakukan difference musiman 1. Pada plot ACF menunjukkan jika data sudah stasioner dalam means karena hanya lag pertama yang melewati selang kepercayaan dan lag 12 pada musimannya.

Plot PACF (Partial Autocorrelation Function) pada gambar 7 setelah dilakukan difference musiman 1. Hasil pada plot PACF menunjukkan bahwa hanya lag pertama yang melewati batas autokorelasi dan pada lag musiman yang melewati garis merah adalah lag 12 dan lag 24. Hasil identifikasi pada plot PACF dan ACF menunjukkan data telah stasioner dalam means. Langkah selanjutnya adalah melakukan identifikasi model sementara untuk mengetahui nilai ordo dari pendugaan Autoregressive Integrated Moving Average yang signifikan.

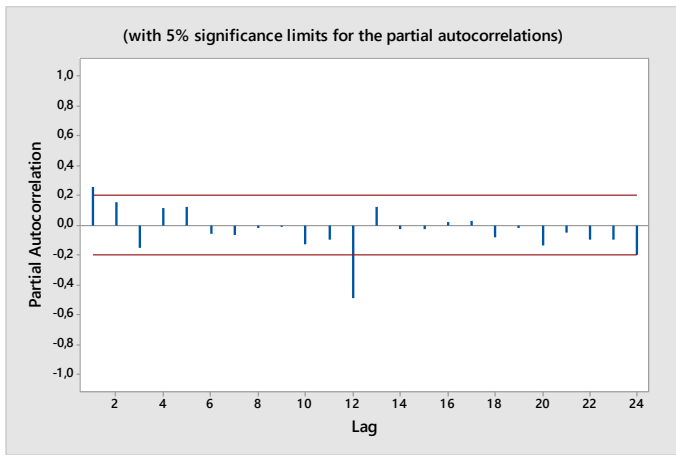

Gambar 7. Plot PACF Data Kasus DBD Difference Musiman 1 


\section{Identifikasi Model ARIMA Musiman Sementara (Tentative)}

Identifikas sementara pada model ARIMA musiman yaitu dinotasikan sebagai ARIMA $(p, d, q)(P, D, Q)^{\mathrm{s}}$ dengan (s) adalah perlambangan dari musimannya. Proses difference pada langkah sebelumnya, dijelaskan bahwa dilakukan proses difference sebanyak 1 kali dan dilakukan difference lagi yaitu difference musiman 1 kali. Model ARIMA sementara yang terbentuk setelah dilakukan difference adalah ARIMA $(\mathrm{p}, 1, \mathrm{q})(\mathrm{P}, 1, \mathrm{Q})^{12}$. Proses selanjutnya yaitu menentukan nilai ordo Autoreggresive (p) dan Moving Average (q) untuk ordo non musiman, Autoreggresive (p) dan Moving Averrage $(Q)$ untuk ordo musimannya.

Nilai ordo dapat dilihat dari plot ACF (gambar 6) dan plot PACF (gambar 7). Plot ACF digunakan untuk membaca nilai moving average ( $q$ dan $Q$ ) sedangkan plot PACF digunakan untuk membaca nilai autoreggresive ( $\mathrm{p}$ dan $\mathrm{P}$ ).

Plot ACF pada gambar 6 menunjukkan bahwa plot ACF cut off setelah lag kedua atau pada lag ketiga sehingga diperkirakan model sementara adalah MA(2). Pada lag musiman terdapat cut off yaitu pada pada lag 12 sehingga SMA(1) untuk model musimannya.

Plot PACF pada gambar 7 menunjukkan bentuk sinusoidal atau menurun menuju ke 0 setelah lag pertama sehingga model sementara $A R(1)$, sedangkan pada lag musimannya menunjukkan jika lag 12 dan lag 24 cut off setelah lag 24 maka model sementara yang diduga adalah SAR(2). Maka hasil identifikasi menghasilkan 4 dugaan model sementara yaitu ARIMA $(1,1,2)(2,1,1)^{12}$

\section{Estimasi Parameter Model}

Proses pendugaan model sementara sudah didapat maka langkah selanjutnya adalah menentukan besarnya nilai parameter koefisien Autoreggresive (AR untuk non musiman dan SAR untuk musiman) serta Moving Average (MA untuk non musiman dan SMA untuk musiman) pada setiap parameter di dalam dugaan model sehingga dapat diketahui layak atau tidaknya parameter tersebut dimasukkan ke dalam model.

Layak atau tidaknya tiap parameter dilihat dari signifikansi tiap parameter. Hipotesis untuk signifikansi parameter model adalah $\mathrm{H}_{0}$ diterima jika tidak signifikan dan tidak masuk ke dalam model. Hipotesis alternatif $\left(\mathrm{H}_{1}\right)$ diterima jika signifikan dan masuk model. Kriteria penolakan jika adalah nilai $\mathrm{P}$ (signifikansi) kurang dari $\alpha$ dengan $\alpha=0,05$ pada tingkat kepercayaan $95 \%$.

Hasil uji signifikansi tiap parameter model pada model sementara ARIMA $(1,1,2)(2,1,1)^{12}$ yaitu nilai signifikansi tiap parameter adalah $\operatorname{AR} 1(0,000)$, SAR1 $(0,003)$, SAR2(0,015), MA1(0,002), MA2 $(0,000)$, dan $\operatorname{SMA}(0,000)$. Parameter dapat masuk ke dalam model jika nilai signifikansi pada tiap parameter adalah kurang dari $\alpha$ dengan nilai $\alpha$ sebesar 0,05 . Hasil yang didapat menunjukkan bahwa model ARIMA musiman sementara yaitu ARIMA $(1,1,2)(2,1,1)^{12}$ memenuhi syarat estimasi parameter. Nilai signifikansi pada tiap parameter di dalam model menunjukkan kurang dari $\alpha(0,05)$ dan masuk ke dalam model.

\section{Pemeriksaan Diagnostik}

Pemeriksaan diagnostik terdiri dari uji white noise dan uji normalitas. Uji white noise suatu model dikatakan baik jika nilai error bersifat acak yang menunjukkan tidak ada autokorelasi yang memiliki arti residual tidak berpola tertentu. Cara melihat proses white noise pada model yaitu dengan menggunakan uji statistik Ljung-Box. Hipotesis untuk uji white noise adalah $\mathrm{H}_{0}$ diterima dan memenuhi asumsi white noise jika nilai signifikansi ( $p$-value) pada Ljung-Box $>\alpha$ dengan nilai $\alpha$ adalah 0,05 .

Hasil dari model ARIMA $(1,1,2)(2,1,1)^{12}$ menunjukkan pada lag 12 dengan $p$-value $=0,211$, lag 24 dengan $p$ value $=0,655$, lag 36 dengan $p$-value $=$ 
0,815, lag 48 dengan $p$-value $=0,160$. Nilai semua $p$-value tersebut lebih dari $\alpha(0,05)$ maka residual pada model ARIMA $(1,1,2)(2,1,1)^{12}$ sudah white noise (tidak ada residual antara lag 12 , lag 24 , lag 36, dan lag 48).

Uji selanjutnya setelah uji white noise yaitu uji kenormalan residual atau uji normalitas. Uji normalitas menggunakan uji Kolmogorov-Smirnov. Uji KolmogorovSmirnov menggunakan residual dari model sementara. Hipotesis untuk uji normalitas adalah $\mathrm{H}_{0}$ diterima jika residual berdistibusi normal. Residual berdistribusi normal jika nilai $p$-value lebih dari $\alpha$ dengan nilai $\alpha$ adalah 0,05 . Residual dinyatakan tidak berdistribusi normal jika $p$-value kurang dari sama dengan $\alpha$.

Hasil uji normalitas menggunakan uji Kolmogorov-Smirnov menunjukkan bahwa p-value pada plot probabilitas residual ARIMA $(1,1,2)(2,1,1)^{12}$ memiliki nilai lebih dari 0,150 . Nilai tersebut lebih besar dari $\alpha(0,05)$, maka residual pada model berdistribusi normal.

\section{Penggunaan Model Terbaik Untuk Peramalan}

Tabel 1. Hasil Peramalan Kasus DBD Tahun 2017-2018

\begin{tabular}{lclc}
\hline 2017 & Peramalan & $\mathbf{2 0 1 8}$ & Peramalan \\
\hline Jan & 1914,22 & Jan & 3455,55 \\
\hline Feb & 1484,58 & Feb & 3091,43 \\
\hline Mar & 1340,06 & Mar & 2351,13 \\
\hline April & 1226,91 & April & 1991,49 \\
\hline Juni & 1157,84 & Juni & 1777,36 \\
\hline Juli & 1048,43 & Juli & 1569,79 \\
\hline Agst & 926,19 & Agst & 1327,93 \\
\hline Sept & 811,60 & Sept & 1210,78 \\
\hline Okt & 768,46 & Okt & 1126,49 \\
\hline Nov & 944,08 & Nov & 1278,36 \\
\hline Des & 1149,58 & Des & 1504,43 \\
\hline Total & 14277,12 & Total & 22384,54 \\
\hline
\end{tabular}

Tahap akhir yaitu menggunakan model terbaik ARIMA musiman yaitu model ARIMA $(1,1,2)(2,1,1)^{12}$ yang sudah memenuhi tahapan uji untuk meramalkan jumlah kasus DBD tahun 2017-2018 di Provinsi Jawa Timur.

Tabel 1 menunjukkan hasil peramalan kasus DBD pada tahun 20172018 atau 24 titik data ke depan di Provinsi Jawa Timur. Pada tabel menunjukkan akan terjadi kenaikan jumlah kasus di masa yang akan datang. Hasil tersebut kemudian divaluasi untuk melihat error atau kesalahan pada model peramalan. Data yang digunakan untuk melihat kesalahan yaitu sebanyak 48 titik data historis, yakni dari Januari 2013 sampai Desember 2016.

Nilai MAPE yang didapat yaitu sebesar 43,51 \% dan nilai MAD adalah 594,05. MAPE (Mean Absolut Percentage Error) adalah persentasi kesalahan atau selisih absolut yang terjadi dantara data aktual dengan data hasil proyeksi atau peramalan. MAD (Mean Absolut Deviation) rata-rata dari nilai selisih absolut dari simpangan data. Hasil peramalan menunjukkan kenaikan atau puncak kasus tetap terjadi pada bulan Januari di tahun 2017 dan 2018.

\section{PEMBAHASAN}

\section{Gambaran Umum Kasus DBD Di Provinsi Jawa Timur}

Metode forecasting dengan data time series tergantung dari pola data yang terdapat pada data aktual periode lampau yang nantinya akan menentukan metode peramalan yang tepat (Yulianti, 2012). Gambar 1 pada plot time series kasus DBD di Provinsi Jawa Timur tahun 2008-2016 menunjukkan adanya pola yang berulang. Pola berulang ini yaitu peningkatan kasus DBD terjadi pada bulan tertentu setiap tahun yang memiliki arti bahwa pada kasus DBD memiliki pola data musiman. Dalam peramalan kasus DBD di Provinsi Jawa Timur tahun 2017-2019, digunakan teknik peramalan Box-Jenkins atau metode ARIMA, dan karena pola data berpola musiman maka metode dikhususkan menjadi model ARIMA musiman.

Metode Box-Jenkins dipakai karena metode Box-Jenkins dapat digunakan pada 
hampir semua jenis data (Rais, 2009), sehingga dapat mengurangi anomali dan kekurangtelitian dalam melihat data. Motede Box-Jenkins juga merupakan perpaduan konsep dari beberapa metode teknik peramalan seperti metode pemulusan, dekomposisi dan regresi sehingga diharapkan menghasilakan peramalan yang lebih jitu (Aritonang, 2009).

Data yang digunakan untuk melakukan peramalan Box-Jenkins harus data yang stasioner (Rais, 2009). Pada kenyataannya tidak banyak data aktual yang ditemui memenuhi syarat data stsioner, kebanyakan data merupakan data yang tidak stasioner (Aritonang, 2009). Data yang integrated harus mengalami proses stasioneritas data (transformasi dan diferensiasi) yang tidak dapat dijelaskan dengan baik oleh autoregresisve model atau moving average model saja karena proses tersebut mengandung keduanya. Campuran kedua model itu disebut Autoregressive Integrated Moving Average (ARIMA). Pola data yang mengandung musiman dapat menggunakan model khusus musiman pada Box-Jenkins yaitu ARIMA musiman karena akan menjadi lebih efektif untuk menjelaskan proses tersebut (Rais, 2009).

Musim penghujan meningkatkan kasus DBD di Provinsi Jawa Timur disebabkan oleh meningkatnya sumber perkembangbiakan nyamuk aedes aegypty di lingkungan sekitar. Tempat seperti bak mandi, tangki air, tempat minum burung, pot bunga, ban bekas, kaleng bekas dan sebagainya merupakan tempat ideal bagi nyamuk untuk berkembangbiak karena akan terisi air pada saat musim penghujan tiba. Tempat perkembangbiakan nyamuk yang meningkat menyebabkan jumlah nyamuk secara keseluruan bertambah sehingga tingkat gigitan nyamuk pada setiap orang akan meningkat. Intensitas gigitan nyamuk yang meningkat tersebut menyebabkan jumlah kasus DBD bertambah setiap musim penghujan tiba.

\section{Peramalan Kasus DBD Di Provinsi Jawa Timur Menggunakan Metode Box- Jenkins}

Metode peramalan Box-Jenkins merupakan metode peramalan deret waktu yang mengabaikan variabel independen dalam prosesnya, sehingga hanya variabel dependen atau variabel waktu yang digunakan (Luluk, 2016). Syarat pada peramalan deret waktu adalah data harus stasioner. Data stasioner dalam rata-rata (means) dan dalam garam (varians). Pada kenyataannya data aktual tidak banyak yang stasioner, dan kebanyakan data aktual merupakan data yang tidak stasioner atau integrated (Aritonang, 2009).

Peramalan kasus DBD di Provinsi Jawa Timur menggunakan metode peramalan Box-Jenkins atau metode ARIMA. Penggunaan metode ini dikarenakan dapat diterapkan pada semua pola data dan dapat digunakan pada data yang tidak stasioner. Pola data yang telah diidentifikasi menunjukkan adanya pola musiman maka metode yang digunakan adalah metode ARIMA musiman.

Pola data kasus DBD seperti pada gambar 1 menunjukkan jika data cenderung naik turun dan berfluktuasi. Ada beberapa titik yang naik secara drastis dikarenakan adanya pola musiman sehingga dapat dikatakan data belum stasioner terhadap means dan varians. Syarat pertama dari peramalan data deret waktu adalah data harus stasioner maka dilakukan proses transformasi agar data menjadi stasioner terhadap varians dan proses difference agar data menjadi stsioner dalam rata-rata (Makridakis, 1999).

Cara melihat data sudah stasioner dalam varians a yaitu dengan melihat Transformasi Box-Cox. Data dikatakan sudah stasioner dalam varians jika nilai lambda $(\lambda)$ atau rounded value pada BoxCox plot adalah 1 atau lebih dari 1 (Wei, 1994). Hasil pemeriksaan stasioneritas data kasus DBD pada varians dengan transformasi Box-Cox pada gambar 2 menunjukkan jika nilai lambda atau 
rounded value (batas interval) pada plot bernilai 0,00 untuk selang kepercayaan $95 \%$. Nilai 0,00 pada rounded value menunjukkan data masih belum stasioner terhadap varians. Nilai rounded value masih belum 1 atau melebihi 1 maka data harus ditranformasikan agar data menjadi stasioner terhadap varians.

Menurut Wei (1994) dalam bukunya yang berjudul Time Series Analysis Univariate and Multivariate Methods, jika nilai lambda $(\lambda)=0$, maka transformasi yang dilakukan pada Box-Cox yaitu transformasi logaritma natural $(l n)$. Transformasi ln digunakan bila data berkaitan dengan waktu dan rata-ratanya mengikuti rata-rata geometrik. Ciri data ini adalah bila rata-rata suatu data semakin besar, maka varians datanya juga semakin besar. Varians yang semakin besar akan menyebabkan homogenitas ragam atau varians antar data tidak terpenuhi. Data yang mempunyai ciri-ciri tersebut adalah data yang berkaitan dengan waktu misalnya seperti data penelitian yang digunakan dalam kasus ini yaitu data kasus DBD yang dilaporkan setiap bulanan.

Nilai rounded value sebesar 0,00 maka data harus ditransformasikan dengan menggunakan persamaan $\mathrm{LnX}_{\mathrm{i}}$ yang merupakan aturan dari transformasi BoxCox agar menjadi stasioner terhadap varians. Hasil transformasi data dapat diketahui pada Gambar 3 bahwa rounded value bernilai 1,37 dengan selang kepercayaam $95 \%$ yang menunjukkan bahwa data sudah stasioner terhadap varians karena lambda $(\lambda)$ bernilai 1 atau lebih dari 1.

Data yang sudah stasioner dalam varians maka langkah selanjutnya adalah pemeriksaan stasioneritas data dalam ratarata (means). Pemeriksaan stasioneritas dalam means dilakukan dengan melihat grafik ACF dari data (Aritonang, 2009). Jika data belum stasioner terhadap means maka akan dilakukan difference. Jumlah difference ini akan menentukan nilai I (integrated). Nilai I dilambangkan dengan ordo (d) dan (D) dalam model.
Gambar 4 memperlihatkan plot ACF data kasus DBD yang sudah mengalami transformasi. Jumlah lag ditentukan dari jumlah data dibagi dengan 4. Garis Merah menunjukkan selang kepercayaan (confidence level) sebesar $95 \%$ dengan tingkat signifikansi atau $(\alpha)=$ $5 \%$ yang merupakan batas signifikan autokorelasi. Data stasioner dalam means dapat dilihat lag yang ditampilkan plot ACF dan PACF, data dikatakan stasioner jika secara umum turun mendekati nol setelah lag kedua

Gambar 4 menunjukkan 3 lag pertama pada plot ACF keluar dari selang kepercayaan, maka dapat dikatakan data belum stasioner terhadap means maka diperlukan proses difference atau diferensiasi tingkat 1. Pada gambar 5 menunjukkan hasil diferensiasi tingkat 1 , menunjukkan jika lag pertama yang melewati selang kepercayan tetapi data masih belum stasioner dalam means. Pada plot ACF dapat dilihat terdapat pencilan atau kenaikan drastis pada lag 12 dan 24 yang dapat disimpulkan terdapat faktor musiman pada data. Hal ini mengindikasikan ada pola musiman setiap 12 bulan sekali. Faktor musiman yang ada pada data tersebut maka dapat dikatakan data belum stasioner terhadap means. Maka dilakukan difference musiman pada data untuk menghilangkan unsur musiman yaitu dengan diferensiasi tingkat 12 sesuai dengan pola musiman yang terjadi setiap 12 bulan sekali.

Hasil diferensiasi musiman pada data terlihat pada Gambar 6 dan 7. Plot ACF menunjukkan jika lag musiman yang melebihi selang kepercayan hanya pada lag 12. Pada plot PACF lag musimannya, lag yang melebihi selang kepercayaan adalah lag 12 dan 24, maka dapat dikatakan data sudah stasioner terhadap means.

Tahap selanjutnya adalah mengidentifikasi model ARIMA musiman sementara. Tahap identifikasi dengan melihat plot ACF dan PACF pada gambar 6 dan 7. Tahap identifikasi akan menentukan ordo Autoregressive $=(p)$ 
untuk non musiman dan ( $p)$ untuk musiman dan juga menentukan ordo Moving Everage $=(q)$ untuk non musiman dan $(Q)$ untuk musiman. Menentukan nilai $d$ (non musiman) dan $D$ (musiman) yaitu dengan melihat data di diferensiasi atau tidak, jika dilakukan diferensiasi 1 kali maka nilai $d=1$, dan seterusnya. Diferensiasi musimannya juga sama, jika tidak dilakukan diferensiasi data maka nilai $D=0$, atau jika dilakukan diferensiasi 1 maka nilai $D=1$, dan seterusnya (Aritonang, 2009).

Plot ACF menunjukkan model Moving Average (MA dan SMA) dan plot PACF menunjukkan model Autoregressive (AR dan SAR). Lag pada plot ACF dan PACF terputus pada lag ke- $p$ dan atau ke- $P$ (musiman) oleh garis merah yang merupakan convidence interval atau garis batas signifikansi autokorelasi maka artinya terdapat korelasi antar data deret waktu pada suatu waktu tertentu hingga lag ke- $p$ atau ke- $P$ masih saling mempengaruhi (berkorelasi), tetapi setelah cut off lag ke- $p$ atau ke- $P$ korelasi tersebut terputus (Yulianti, 2012). Hasil identifikasi pada plot ACF dan PACF menunjukkan model sementara adalah ARIMA $(1,1,2)(2,1,1)^{12}$.

Tahap selanjutnya adalah uji signifikansi parameter dan pemeriksaan diagnostik. Uji signifikansi parameter model dilakukan dengan statistik $t$ atau menggunakan $p$-value untuk menguji apakah koefisien model secara individu berbeda dari nol. Pada analisis regresi, ciri model yang baik adalah jika semua koefisien model secara statistik berbeda dari nol. Koefisien variabel jika tidak signifikan maka variabel tersebut harus dilepas dan melakukan spesifikasi dengan model lain yang sudah diduga dan diuji (Aritonang, 2009). Model diterima jika nilai signifikansi setiap parameter dalam model kurang dari $\alpha$ dengan nilai $\alpha$ adalah 0,05 . Hasil analisis menunjukkan jika nilai signifikansi setiap parameter kurang dari $\alpha$ maka $\mathrm{H}_{0}$ diterima dan memenuhi uji signifikansi parameter.
Langkah selanjutnya yaitu melihat nilai signifikansi pada Ljung-Box untuk mengetahui apakah residual mengikuti proses white noise. Hasil uji white noise menunjukkan pada nilai signifikansi lag 12, lag 24, lag 36 dan lag 48 lebih dari 0,05 sehingga model sudah memenuhi syarat uji white noise dan error bersifat acak serta tidak ada autokorelasi pada data. Langkah terakhir dalam pemeriksaan diagnostik adalah uji kenormalan residual. Uji ini menggunakan uji normalitas Kolmogorov-Smirnov. Hipotesis yang diuji adalah residual berdistribusi normal jika $p$-value lebih dari $\alpha(0,05)$. Residual tidak bersitribusi normal jika nilai $p$-value kurang dari sama dengan $\alpha$ dengan nilai $\mathrm{o}=0,05$ (Aritonang, 2009). Hasil uji Kolmogorov-Smirnov menunjukkan nilai $p$-value adalah lebih dari 0,150. Nilai tersebut lebih dari $\alpha$ sehingga hipotesis diterima dan residual bersifat normal.

Model pada metode peramalan Box-Jenkins disebut layak dan baik jika sudah memenuhi asumsi yaitu uji signifikansi parameter, uji white noise dan uji normalitas residual (Aritonang, 2009). Hasil uji yang telah dilakukan menunjukkan jika model ARIMA $(1,1,2)(2,1,1)^{12}$ sudah layak untuk dipergunakan.

Hasil peramalan untuk 24 periode ke depan menunjukkan kasus DBD akan meningkat selama 2 tahun mendatang. Puncak tertinggi terjadi pada bulan Januari yang menunjukkan jika peningkatan kasus DBD terjadi seiring dengan pergantian musim kemarau ke musim hujan.

Akurasi dari peramalan dianggap sebagai kriteria penolakan dalam memilih metode peramalan. Hasil peramalan kasus DBD menunjukkan jika nilai MAPE adalah 43,51\%. Jika nilai MAPE menunjukkan rentang antara 20-50\% maka hasil peramalan dikatakan cukup baik, layak dan memadai. Nilai MAPE yang cukup besar dapat diakibatkan oleh pergeseran iklim yang menyebabkan 
musim dan cuaca tidak menentu (Aridini el $a l, 2015)$.

\section{Peramalan Kasus DBD Di Provinsi Jawa Timur tahun 2017-2018}

Total jumlah peramalan kasus DBD pada tahun 2017 adalah 14.277,12 menurun dibandingkan tahun sebelumnya yaitu 24.461 kasus DBD. Hasil peramalan menunjukkan angka kenaikan pada tahun 2018 yaitu sebanyak 22.384,54 kasus DBD. Puncak tertinggi kasus DBD tetap terjadi pada bulan Januari setiap tahun pada 2 tahun mendatang jika melihat dari hasil peramalan. Penelitian yang dilakukan Iriani (2012) menunjukkan puncak kasus DBD berkorelasi dengan puncak curah hujan pada musim penghujan.

Iklim merupakan salah satu faktor terpenting dalam DBD (Margaretha, 2007). Iklim yang sesuai akan mempengaruhi perkembangbiakan vektor nyamuk DBD. Iklim akan mempengaruhi musim dan cuaca harian di wilayah tersebut. Perwitasari (2015) mengatakan bahwa pergeseran peningkatan kasus DBD dikarenakan musim penghujan yang terjadi pada bulan tersebut. Hasil penelitian yang dilakukan oleh Sitorus (2003) mengatakan bahwa sebanyak $120 \%$ peningkatan kasus DBD dipengaruhi oleh curah hujan bulanan.

Jumlah kasus DBD berkaitan dengan curah hujan di wilayah tersebut (Mustazahid, 2013). Penelitian yang dilakukan Sulasmi (2013) juga menunjukkan jika curah hujan mempunyai pengaruh dominan terhadap kejadian DBD, semakin tinggi intensitas curah hujan maka akan menimbulkan lebih banyak genangan air hujan yang berpotensi menjadi tempat yang potensial untuk perkembangbiakkan larva nyamuk aedes. Musim hujan dengan frekuensi hujan yang tinggi akan meningkatkan jumlah tempat dan habitat perkembangbiakan vektor. Vektor ini mempunyai larva yang hidupnya di air untuk perkembangan pupa. Nyamuk yang berkembangbiak semakin banyak, maka akan terjadi peningkatan intensitas gigitan kepada manusia, sehingga pada musim hujan kemungkinan jumlah kasus penyakit DBD akan meningkat (Fathi et al., 2005).

Hasil peramalan yang diperoleh diharapkan dapat membantu upaya penanggulangan DBD di Provinsi Jawa Timur yang telah dilakukan oleh pemerintah dan Dinas Kesehatan Provinsi selama bertahun-tahun. Tahapan dalam memberantas dan meminimalisir DBD yang pertama yaitu dengan melakukan surveilans DBD yang bertujuan untuk memantau kecenderungan dan tren dari DBD dan melakukan kewaspadaan dini akan adanya KLB (Kejadian Luar Biasa).

Kewaspadaan dini juga dilakukan sebelum musim penularan (SMP). SMP adalah periode bulan dengan rata-rata terendah selama 3-5 tahun terakhir. Pengendalian yang dilakukan masa SMP yaitu adanya penyuluhan kepada masyarakat, Bulan Bakti Gerakan (BBG) PSN 3M plus yang dilaksanakan serentak oleh masyarakat, kemudian dilakukan larvasidasi secara selektif ke tempat penampungan air (TPA) dan tempat non TPA yang berpotensi menjadi tempat perindukan nyamuk aedes (Kemenkes RI, 2015).

Penyelidikan Epidemiologi (PE) dan Penanggulangan Fokus (PF) dilakukan jika terdapat kasus DBD di wilayah tersebut. PE bertujuan untuk mengetahui potensi penularan dan penanggulangan DBD lebih lanjut serta tindakan penanggulangan yang perlu dilakukan di wilayah penularan dan untuk menetukan PF yang akan dilakukan. PE yang sudah dilakukan sebelumnya setelah terdapat kasus, maka tindakan PF yang dilakukan antara lain yaitu penggerakan masyarakat dalam PSN DBD dan larvasidasi, melakukan penyuluhan dan fogging dengan insektisida.

Kasus DBD di Provinsi Jawa Timur tidak hanya dibebankan pada sektor kesehatan tetapi harus ada kerjasama dengan sektor lain. Kerjasama lintas sektor perlu ditingkatkan seperti dengan sektor pendidikan dan kebudayaan, agama, 
kebersihan, pariwisata, dan sektor-sektor lain yang terkait secara langsung dan tidak langsung agar program berjalan dengan baik. Partisipasi dari berbagai pihak juga sangat dibutuhkan, tidak hanya pemerintah selaku pemegang program tetapi juga meliputi petugas kesehatan, kader dan khususnya peran aktif dari berbagai lapisan masyarakat untuk mendukung dan ikut serta dalam program-program yang ada maupun yang akan dilakukan agar kasus DBD di Provinsi Jawa Timur kemudian hari dapat terus diturunkan dan diminimalisir.

\section{SIMPULAN}

Peramalan menggunakan metode ARIMA musiman untuk meramalkan jumlah kasus DBD di Provinsi Jawa Timur menghasilkan model terbaik yaitu ARIMA $(1,1,2)(2,1,1)^{12}$. Model ARIMA $(1,1,2)(2,1,1)^{12}$ memenuhi semua asumsi yang diperlukan sebagai syarat peramalan menggunakan metode ini. Asumsi yang diperlukan yaitu uji signifikansi parameter dan uji diagnostik.

Hasil peramalan menggunakan model terbaik menghasilkan pada tahun 2017-2018 di Provinsi Jawa Timur akan terjadi peningkatan selama 2 tahun mendatang. Hasil peramalan juga menunjukkan puncak kasus DBD tertinggi terjadi pada bulan Januari 2017 dan Januari 2018. Hasil tersebut mengikuti data aktual di tahun sebelumnya. Hasil peramalan kasus DBD memberikan nilai MAPE sebesar 43,51\%. Nilai tersebut menunjukkan jika peramalan adalah cukup baik, layak dan memadai.

\section{DAFTAR PUSTAKA}

Aritonang, L. 2009. Peramalan Bisnis. Jakarta : Ghalia Indonesia.

Ardini, S.R., Nita, A., Fedri, R. 2015. Dampak Perubahan Iklim Terhadap Kejadian Demam Berdarah Di Jawa Barat. Jurnal Ilmu Kesehatan Masyarakat. Jawa Barat:
Universitas Padjajaran. Vol 1: 4347.

Baroroh, N. 2013. Analisis Pengaruh Modal Intelektual terhadap Kinerja keuangan Perusahaan Manufaktur di Indonesia. Jurnal Dinamika Akutansi. Vol 5(2): 173-182.

Fathi, Keman, S., Wahyuni, C.U. 2005. Peran Faktor Lingkungan dan Perilaku terhadap Penularan Demam Berdarah Dengue di Mataram. Jurnal Kesehatan Lingkungan. Vol 2(1): 1-10.

Halide, Halmar, Rais dan P. Ridd. 2011. Early Warning System for Dengue Hemorrhagic Fever (DHF) Epidemics in Makassar. Jurnal Matematika Dan Sains. Juli 2011.Vol 16 No 2.

Iriani, Y. 2012. Hubungan antara Curah Hujan dan Peningkatan Kasus Demam Berdarah Dengue Anak di Kota Palembang. Jurnal Sari Pediatri. Vol 13(6): 378-383.

Kemenkes RI. 2010. Buletin Jendela Epidemiologi. Pusat Data dan Surveilans Epidemiologi Kementerian Kesehatan RI

Kemenkes RI. 2015. Pedoman Pengendalian Deman Berdarah Dengue Di Indonesia. Jakarta :Kementerian Kesehatan RI.

Luluk N.K. 2016. Aplikasi ARIMA Untuk Meramalkan Jumlah DBD Di Pusksmas Mulyorejo. Jurnal Biometrika dan Kependudukan. Surabaya: Universitas Airlangga. Vol 5(2): 177-186.

Makridakis, S., Wheelwright, S.C., Victor, E.M. 1999. Metode dan Aplikasi Peramalan, second edition. Erlangga: Jakarta.

Margaretha, M.S. 2007. Pengaruh Iklim Terhadap Kasus Demam Berdarah Dengue. Jurnal Kesehatan Masyarakat. Jakarta: Universitas Trisaksi. Vol 2(1): 11-18.

Mustazahid, A.W. 2013. Hubungan Kejadian Deman Berdarah Dengan Iklim di Kota Semarang Tahun 
2006-2011. Unnes Journal of Public Health. ISNN 2252-6528.

Perwitasari, D., Yusniar, A. 2015. Model Prediksi Demam Berdarah Dengue dengan Kondisi Iklim di Kota Yogyakarta. Jakarta: Pusat Teknologi Intervensi Kesehatan Masyarakat.

Dinkes Provinsi Jawa Timur. 2016. Profil Kesehatan Jawa Timur. Surabaya. 2015

Rais. 2009. Pemodelan Data Time Series dengan Metode Box-Jenkins. JIMT. Jurnal Matematika, Fakultas Matematika dan Ilmu Pengetahuan Alam. Tadulako: Universitas Tadulako. Vol. 6 (1), pp. 1-10.

Sitorus, J. 2003. Hubungan Iklim dengan Kasus Penyakit Demam Berdarah Dengue di Kotamadya Jakarta Timur Tahun 1998-2002. Tesis. Universitas Indonesia.

Srikiatkhachorn A. 2010. Dengue Hemorrhagic Fever: The Sensitivity and Sensitivity of the WHO Definition for Identification of Severe Cases of Dengue in Thailand, 1994-2005. Clinical Infectious Diseases. 50:1135-1143.

Sulasmi, S. 2013. Kejadian Deman Berdarah Dengue Kabupaten Banjar Berdasarkan Data Curah Hujan Normal Bulanan. Jurnal
Epidemiologi dan Penyakit Bersumber Binatang. Vol 4 (4): 171-174.

Sukowati S., Achmadi U.F., dan Sudjana P. 2010. Demam Berdarah Dengue. Buletin Jendela Epidemiologi. Vol 2(1): 20-26.

Tantawichien, T. 2012. Dengue Fever and Dengue Haemorrhagic Fever in adolescents and adults. Paediatrics and International Child Health .Vol 32 :22-27.

Wahyono T., Haryanto., Budi., Mulyono., Sigit., Adiwibowo.,Andrio. 2010. Faktor-faktor Yang Berhubungan Dengan Kejadian Demam Berdarah dan Penanggulanganya di Kecamatan Cimanggis, Depok, Jawa Barat. Buletin Jendela Epidemiologi. Vol 2.

Wei, W.S. 1994. Time Series Analysis: Univariate and Multivariate Method. Addison Wesley Publishing Company. New York.

Yulianti, F. 2012. Modelling dan Forecasting Tingkat Produksi Gas di Indonesia Menggunakan Metode ARIMA. Skripsi. Depok: Fakultas Teknik Program Sarjana Teknik Industri Universitas Indonesia. 